\title{
Research on the Construction of College Students' Ideological and Political Education Discourse Power Based on Internet Thinking
}

\author{
Qingshan Yang \\ United Front Work Department \\ Guilin University of Electronic Technology \\ Guilin, China
}

\author{
Yuntian Ma* \\ School of Mechanical and Electrical Engineering \\ Guilin University of Electronic Technology \\ Guilin, China
}

\begin{abstract}
Internet thinking is considered as a new way of thinking, which not only influences the values of young college students but also makes new requests for the construction of ideological and political education discourse power in universities and colleges. Facing the effect of the Internet thinking, how to choose a better way to establish the ideological and political education discourse power of college students has become an essential issue to be solved in the new era of ideological and political education. In order to bring about the construction of college students' ideological and political education discourse power effectively, it is necessary to use the power of users' thinking to create a "people-oriented" discourse concept; unite the meaning of iterative thinking and integrate the new discourse resources advanced with times; take advantage of platform thinking to build an "online to offline" service channel. It is essential to hold the discourse power of ideological and political education in the face of changing circumstances, to better train new humans to take on the great responsibility of national rejuvenation.
\end{abstract}

Keywords-Internet thinking; ideological and political education; discourse power; construction

\section{INTRODUCTION}

With the rapid development of Internet technology, the construction of college students' discourse power in ideological and political education should keep pace with the times to stay young and lead the future. The theoretical thinking of each age is a kind of historical product, which possesses different forms and contains different contents. [1] Internet thinking, as a new way of thinking, presents the characteristics of equality, interaction, openness and innovation, and has a significant influence on the ideological and political education of college students in the Internet era. To adapt to the new normal of social development, the construction of college students' ideological and political education discourse power should learn from Internet thinking, on this account to promote the development and innovation of college students' ideological and political education.

\section{THE MAIN FEATURES OF INTERNET THINKING}

\section{A. Internet thinking advocates equality and openness}

Equality is an important feature of Internet thinking. In a virtual network, there are no more distinctions of status and

Fund program-Innovation Project of Guangxi Graduate Education “The Discourse Study among Undergraduate Students' Ideological and Political Education under New Media Environment”(Project number YCSW2017149). position between people, and open dialogues and ideas are produced within the scope of the law which thrown up allaround. The openness of the network has broken the asymmetric pattern of original offline communication, changed the mechanism of original offline dialogue, and has implemented a new construction of Internet discourse power to achieve equal dialogue in the process of network interaction. The Internet turns the world into a global village, changing the present situation of interpersonal communication and restoring the original pattern of communication. All of these are benefited from the openness of the Internet. The openness of the Internet has brought about an entrance without any admission and threshold to access and visit the outside world. The openness of the Internet accommodates too much information and reaches an unprecedented new opening trend. This openness is the latest presentation that highly accords with the development of the times.

\section{B. Internet thinking advocates diversity and innovation}

The Internet is a multi-prism mirror that refracts and reflects the real society. Due to the different aspects, positions, and orientation, the Internet shows its diversity and polymorphism. [2]In the Internet age, the objectification of information dissemination has realized the diversification of communication subjects;“ ask Baidu if you have questions,” reflects the richness and variety of network information resource; the pattern of information dissemination embodies the feature of diversity most. The formation of multiple thoughts is benefited from innovative thinking. In other words, innovation is the primary feature of Internet thinking and the latest driving force to lead development. The Internet, especially the wide application of the Internet, has brought rapid changes to the world. It is also the social benefit comes from the innovative Internet thinking. On the contrary, ways of thinking and solving problems that disregard conventional rules, such as anti-hack, anti-logical and counter thought, have made everything possible and broke the fixed pattern of thinking, realize the innovation. The openness of the Internet has pushed forward the human innovation and made innovation become reality.

\section{Internet thinking highlights interactivity and experience}

The process of using the Internet needs human participation and interaction, so the interactivity and participatory are 
emphasized. The emerge of the Internet provides a new transmission field since the traditional information spreads like running water and seldom has inverse flow and feedback, even without connection and interaction. Internet thinking has turned the traditional pattern of one-way information flow to two-way or multidirectional communication which promotes the individual motility and stimulates the motivation of equal conversation and interactive exchange among two-way or multiple ways. Under the environment of the Internet, "immersion" is an obvious feature of experience, where the "participation" and "experience" of "users" are the true portrayal of Internet thinking. "Users' own experience can better reflect their sense of existence. Diversified Internet environment provides multiple experience platforms, and users' own experience and feelings make the facts more convincing.

\section{THE INFLUENCE OF INTERNET THINKING ON THE} CONSTRUCTION OF IDEOLOGICAL AND POLITICAL EDUCATION DISCOURSE POWER

\section{A. Equal and open thinking infuses the idea of ideological and political education}

In the Internet age, only to keep pace with the times can better guide lead students' thoughts. In traditional ideological and political education activities, teachers always hold the discourse power since this is the intangible right that comes from the special nature of the discipline. In this way, not only the identity and obedience to ideological and political education discourse power of college students can be guaranteed, but also the high unity of both sides in political thoughts and understanding, which plays a very important role in promoting the effective development of ideological and political education. In the Internet age, the traditional educational ideas such as "from top to bottom" and "rule by the voice of one man alone" have shown their inadaptability. The "student-centered" and "three closes" approaches still need to be deepened. The equality and openness of Internet thinking break the pattern of educators' leading position in ideological and political education and requires a more equal and open educational concept applied in colleges and universities' ideological and political education. In other words, we should consider what students want, what students need urgently, and put students' requests in the first place, and respect students' dominant position. Therefore, ideological and political teachers should be familiar with the features of equality and openness of Internet thinking, constantly change the original educational ideas, know the new requirements of Internet thinking on the reform of educational ideas, and do an in-depth research to study the demand behavior and demand psychology of students under the influence of Internet thinking, so as to guide the direction for the healthy development of students.

\section{B. The content of ideological and political education is dissolved by multi-innovation thinking}

In the process of ideological and political education, the dissemination of educational content is the expression form of discourse power and an essential factor linking the educator and educatee. The content of traditional ideological and political education is huge and theoretical, which is the result corresponding to the social development requirements at that time. In the Internet era, the advantage of traditional ideological and political education discourse power is no longer prominent. It is because the content of ideological and political education failed to take the opportunity of Internet widely applied and failed to achieve leap-forward development with the help of the Internet. The most significant feature of the Internet thinking is the rapid speed of reflection, while the iterative updating of ideological and political education content leaves behind the pace of Internet thinking, which melts the expression of ideological and political education discourse power. In the social transformation era, young college students have multiple thoughts and various needs. Only by continuous changing discourse style and iterating, can the content of ideological and political education better unite and direct young college students." Get rid of pure instrument rationally, and then gradually establish their own discourse and theoretical system, highlighting the instrumental rationality and value rationality of ideological and political education discourse.”[3] Consequently, the current ideological and political education content not only needs "magnificent and classy" theory as the foundation but also needs to constantly develop new areas, integrate Internet thinking, capture the right point, design and launch new content that young college students love to hear and easy to learn.

\section{Interactive experience thinking impact ideological and political education mode}

In traditional ideological and political education, educational information is transmitted mainly through "one speaking and the other listening" classroom where the information flows in one direction. To some extent, ideological and political education activities are just like a "one-act play" of educators, with little interaction and scenarios between the educators and educatees. The educational goal is clear, but on the contrary, the educational effect is under-expected and should be strengthened. The rapid development of Internet technology has an effect on the traditional ideological and political education, but also provided good technical support for the application of emerging media to spread educational value. The interactivity of the Internet promotes the reform of education pattern, realizes the equal dialogue and stimulates the argument between the two parties of education, and meanwhile provides a platform and develops new channels to achieve a "chorus of education". By "placing" Internet to college students' ideological and political education, in one side, we can arouse the working enthusiasm of educators, stimulate the new education resources development and creation, thus enriching the content and broaden the channels of education, and promote the ideological and political education to adapt the social development of science and technology, to make comprehensive education work reach a higher level. On the other side, college students are more willing to accept and participate in ideological and political education activities by the abundant forms of networked and dynamic ideological and political education. In the process of surfing on the Internet, college students receive positive energy invisibly and take advantage of a network platform to spread their own values and ideas. Only by constantly promoting the collaborative innovation of ideological and political education can we better advance the all involved education and enhance the effectiveness of discourse power. 


\section{The CONSTRUCTION OF Discourse POWER IN IDEOLOGICAL AND POLITICAL EDUCATION OF COLLEGE STUDENTS BASED ON INTERNET THINKING}

\section{A. By the power of user thinking, to create a new concept of people-oriented discourse}

The user's concept is the primary content of Internet thought, and the "customer first service" is the core viewpoint of user thought. In the Internet era, enterprises put the "customer first service" into an important place as their law of survival. The network information spreads with a user-centric way, which changes the original information-spread mode like running water. In exchange, the mode changes to multidirectional interactive communication that enterprises and users have direct interaction and communication. In addition, the importance of users' opinions and feedback is increasing with each passing day, and users' voices are more intimidating and their discourse power is growing. Chairman $\mathrm{Xi}$ pointed out that to do well in ideological and political work in colleges and universities, it is necessary to adapt and change with the times and circumstances.[4] In the Internet era, the ideological and political education discourse power should be constructed with the help of user thinking, taking "users"- students' needs as the orientation. We should create a new concept of "peopleoriented" or student-oriented discourse and improve the students' identification degree of ideological and political education discourse power, in order to achieve the maximisation of ideological and political education discourse power.

In ideological and political education, with the participation of "user first", it is necessary to change the original discourse concept and create a new concept reflecting the studentoriented. The popularisation of Internet applications has broken the discourse idea of traditional ideological and political education. Therefore, educators should change their concepts, draw lessons from the virtuality of the Internet to weaken the identity awareness of both parties of education, and implement the knowledge exchange between the two parties of education in an equal manner. Moreover, learn from the openness of the Internet to expand the contact area between the two parties of education, and realize humanistic care for college students in an inclusive manner. According to the features of contemporary college students, such as individualized points, diversified appeals and disordered structure, the choice of ideological and political education content should be guided by the needs of students and combine with the development regulation and the requirements of the times. Thus the new content can be created in the Internet era where the "private customisation" of ideological and political education discourse occurs. Indoctrination methods such as "rule by the voice of one man alone" and "spoon-fed" are no longer meet the requirements of college students' growth and success. It is more scientific to construct an equal and interactive education model to activate students' learning atmosphere; to build a pluralistic and experiential teaching environment to mobilize students' enthusiasm for learning. We should fully respect students' choices and use a language style that is easily accepted by students to accept, so as to construct a new student-centered discourse concept.

\section{B. Combining the iterative thought and integrating the new discourse resources advanced with times}

Iterative thinking refers to prompt responding, which is the timely reception, processing, and distribution of all types of information (including the development and audience demands).[5] With the advent of the Internet age, iterative thinking has appeared everywhere and all the time. The progress of science and technology drives the constant upgrading of various information and products. Enterprises could make timely adjustments according to users' information feedback on product information and continue to upgrade to maximally meet users' needs, which is the right application of iterative thinking. The integration of ideological and political education discourse resources in this new era should put iterative thinking in. It is to combine ideological and political education with the most prevalent discourse content and the latest expression at the fastest speed, in order to make the discourse power catch the pace with the times. This is the best choice to stimulate the development vitality of ideological and political education and meet the growth requirements of young college students. In one sense, the abundant discourse resources are merged into ideological and political education by iterative thinking, which enhances the attraction of ideological and political education discourse.

Choosing educational content bases on the needs of students, so the popular discourse should be included in education to enrich the discourse resources of ideological and political education. There are plenty of discourse resources in traditional Chinese culture with a deep inside power. The publication of the "Xi Jinping quotation" has generated a new culture taste, applying the old words in the present and updating the iterative meaning. Thus, the ideological and political education discourse in the Internet era needs to be enriched by traditional culture. Iterative thinking is more appropriate in the application of the latest theoretical achievements in the sinicisation of Marxism. While combining network propagation rule and demand for the development of college students, using easily understood, fresh, populist and daily used discourse, the content of the ideological and political education could be updated with the help of the Internet. Moreover, a brand new discourse system is used to stimulate college students' enthusiasm for learning and practice, and lead young college students to strengthen their sense of discourse power.

\section{Take advantage of platform thinking to build new "online to offline" service channels}

The network platform is the "hub" and "broadcasting station" for all kinds of information. The functioning of the Internet mainly depends on the network platform, where promoting the formation of platform thinking and providing new impetus for innovation and development. Platform thinking is an open, sharing and all-win thought, which focuses on creating an "ecosystem" of promoting common values, ideas, and thoughts. The ideological and political education should be carried out wherever the young students are. Nowadays, the Internet has become a part of college students' life. Thus the new platform, relying on the Internet, of ideological and political education will be built based on the students' needs. The inevitable trend of enhancing the 
discourse power of ideological and political education of college students in the new era is the common demand of discipline development and social progress of ideological and political education. It is an inevitable trend of intensifying the discourse power of ideological and political education in this new era, with the common demand from ideological and political education discipline development and social progress. In the Internet era, the establishment of platform thinking is helpful to promote the diversification of ideological and political education carriers, actively take a new position and broaden educational service channels. Also, it helps to promote the dissemination of ideological and political education content and make education more effective.

In the Internet age, it is an effective way to maximize the coverage area of an ideological and political education by applying the advanced scientific technology, pushing original content and building a network platform that shared and spread by every college student. There are two ways to establish an online platform: build a new one, which is a process of coming from nothing. Take contemporary young college students as an example, to combine development regulation of ideological and political education and the dissemination characters of network media, to use latest web technology, to develop new applications of ideological and political education such as the four "LightApp" in Guangxi Eclass, are the positive instances. The other way is making the best of the existing platform. The current resources can be arranged, developed and reused on the updating platform, in order to improve the frequency of using, maximize the influence of platform among students and strengthen the online ideological and political educational system. Certainly, offline practical education should not be abandoned when considering all the advantages of the network platform. Offline education is the basis of online education because online education outstanding achievements would finally come to offline practice. They complement each other while conducting both online and offline simultaneously. It calls for construction of concentric circles of online and offline ideological and political education, and jointly exploit new channels of "online to offline" ideological and political education services.

\section{REFERENCES}

[1] Selections of K. Marx and F. Engels. vol. 4, 1995. Beijing: People's Publishing House. (In Chinese)

[2] B. Zhou, Several inspirations from "Internet thinking". Chongqing Daily. (In Chinese)

[3] R. Qiu, Political education discourse research: current issue and future development. Journal of ideological and theoretical education. (In Chinese)

[4] J. Xi, Make the ideological and political work penetrate the whole education process and create a new situation for the development of higher education in China. China Daily. (In Chinese)

[5] M. Li, Y. Zhang, C. Liu, R. Gao, Improvement and innovation of public opinion guidance under Internet thinking. Xi'an Jiaotong University (social science edition). (In Chinese) 